\title{
The Behavior of Conventional and Islamic Bank Deposit Returns in Malaysia and Turkey ${ }^{1}$
}

\author{
Serhan Cevik \\ International Monetary Fund, $70019^{\text {th }}$ Street, N.W. \\ Washington, D.C. 20431, USA. Email: scevik@imf.org \\ Joshua Charap \\ International Monetary Fund, $70019^{\text {th }}$ Street, N.W. \\ Washington, D.C. 20431, USA. Email: jcharap@imf.org
}

\begin{abstract}
This paper examines the empirical behavior of conventional bank deposit rates and the rate of return on retail Islamic profit-and-loss sharing (PLS) investment accounts in Malaysia and Turkey, using monthly data from January 1997 to August 2010. The analysis shows that conventional bank deposit rates and PLS returns exhibit long-run cointegration and the time-varying volatility of conventional bank deposit rates and PLS returns is correlated and is statistically significant. The pairwise and multivariate causality tests show that conventional bank deposit rates Granger cause returns on PLS accounts. These findings have policy implications in terms of price stability and financial stability.
\end{abstract}

Keywords: Interest rates; Islamic banks; causality; time-varying volatility correlation JEL Classifications: E42; E43; E49; F59; G14; G15; O16

\section{Introduction}

Islamic banking has emerged as a mainstream alternative to conventional finance in a growing number of countries. ${ }^{2}$ Along with the global expansion of conventional modes of financing, the Islamic banking industry has grown significantly since its inception in the early 1970s and moved beyond the confines of a niche market, largely due to greater financial liberalization and an unprecedented inflow of petrodollars to the Middle East (Imam and Kpodar, 2010). The combined balance sheets of Islamic banks grew from $\$ 150$ billion in 1990 to about $\$ 1$ trillion in 2010, with more than 300 sharia-compliant institutions operating in 80 countries. While the share of Islamic banking is still small compared to conventional finance at about 1 percent of the global banking system, there is growing interest in sharia-compliant institutions and instruments. Some researchers have argued that Islamic financial institutions are a viable alternative to promote economic growth and are better-suited to absorb macro-financial shocks because of structural advantages over the conventional banking model (Dridi and Hasan, 2010; Ebrahim and Safadi, 1995; Khan, 1986; and Mills and Presley, 1999). On the other hand, El-Gamal (2005) and others have concluded that Islamic finance simply seeks to replicate the functions of conventional financial instruments and is primarily a form of rent-seeking legal arbitrage. The purpose of this study is to offer an empirical analysis of the behavior of conventional bank deposit rates and the rate of return on retail sharia-compliant profit-and-loss sharing (PLS) investment accounts in two countries where both systems operate. ${ }^{3}$

\footnotetext{
${ }^{1}$ Disclaimer: The views expressed herein are those of the authors and should not be attributed to the IMF, its Executive Board, or its management.

${ }^{2}$ Islamic banking operates according to the principles of the sharia - the Islamic code of law and behavior based on the Quran, the sunnah, which incorporates the sayings, practices, and teachings of the Prophet Mohammed, and jurisprudence, which extends the application of the sharia, through comparative analogy and the consensus view of the religious scholars, to issues that are not directly addressed in the primary sources.

${ }^{3}$ This paper examines retail Islamic banking, which relies on retail depositors seeking relatively stable returns and access to liquidity, rather than Islamic investment banks or investment companies.
} 
The data reveal a high degree of correlation between conventional deposit rates and the rate of return on retail PLS accounts in Malaysia and Turkey. ${ }^{4}$ Between January 1997 and August 2010 the correlation of one-year term conventional bank deposit rates and the rate of return on PLS accounts was 91 percent for Malaysia and 92 percent for Turkey (Figure 1). Moreover, the time-varying volatility of conventional deposit rates and PLS returns were correlated. Islamic banks, however, are not permitted to charge interest per se and are obliged to adhere to the principle of risk sharing in financial intermediation, which means that PLS returns should be linked to the profitability of investments. Accordingly, although conventional and sharia-compliant banks operate in the same macroeconomic environment, it is still interesting to find that the rate of return on retail PLS accounts closely tracks interest rates offered by conventional banks in Malaysia and Turkey

In theory, the Islamic model of banking adheres to the principles of equity participation and risk sharing since sharia-compliant banks derive their earnings from venture financing-type investments. While funding activities are mainly carried out through the participatory PLS model, it is well-established in the literature that Islamic banks follow their conventional counterparts in creating assets through non-PLS, debt-like instruments with a pre-determined, fixed rate of return, in line with the findings of Beck, Demirguc-Kunt and Merrouche (2010) that there are "few significant differences in business orientation, efficiency, asset quality or stability" between conventional and retail Islamic banks. As a result, given the implicit link to interest rates on the asset side of the balance sheet, PLS returns follow conventional bank deposit rates. Such correlations have been observed in other studies. In the case of Malaysia, for example, Chong and Liu (2009) found that retail Islamic deposit rates mimic the behavior of conventional interest rates.

Figure 1. Conventional and Islamic One-Year Deposit Returns
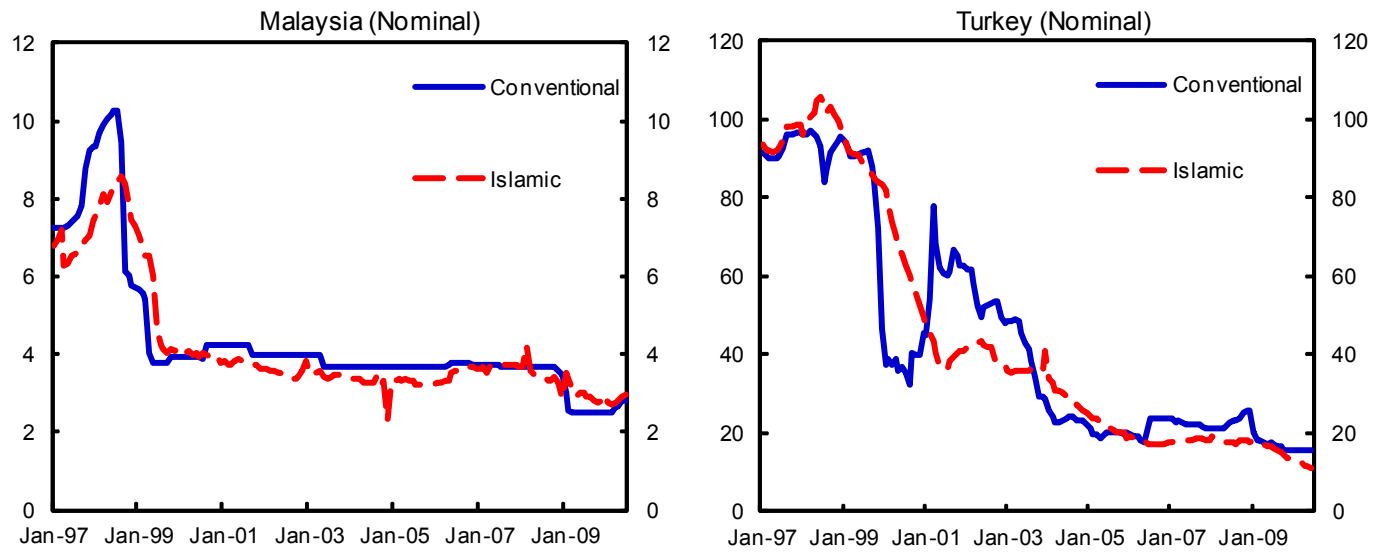

Sources: Central Bank of Malaysia, Central Bank of Turkey, and Turkish Participation Banks Association.

Empirical analysis shows cointegration, causality and volatility correlation between conventional and retail Islamic bank deposit returns. Based on the Johansen cointegration methodology, the rates of return on PLS accounts and conventional bank deposit rates are found to be cointegrated in both Malaysia and Turkey. Moreover, in Malaysia and Turkey conventional interest rates Granger cause the rate of return on Islamic investment accounts both in levels and first differences: PLS returns are determined partly by conventional interest rates. Since the pairwise Granger causality test may produce misleading results when the true nature of the relationship involves a common third process, additional variables are introduced within a vector error correction model (VECM) and confirm the unidirectional causal relationship from conventional interest rates to PLS return. The impulse response function and variance decomposition of the VECM are analyzed and provide further evidence on the sign and timing of the adjustment of PLS returns to changes in conventional interest rates and consumer price inflation. Furthermore, the time-varying volatility

\footnotetext{
${ }^{4}$ Limitations in data availability prevented a comparable analysis for other countries.
} 
pattern of conventional and Islamic bank deposit returns is investigated by using the rolling standard deviation and volatility correlation of the two series and demonstrates that there is a high, and statistically significant, correlation between volatility of conventional interest rates and PLS returns in both Malaysia and Turkey.

The remainder of the paper is structured as follows. Section II provides an overview of the basic principles and instruments of Islamic banking. Section III provides some factual observations on the implementation of the sharia-compliant model of banking. Sections IV and V outline the data used in the analysis and the econometric techniques employed, respectively. Section VI focuses on interpreting empirical results, while Section VII offers concluding remarks.

\section{Basic Principles and Instruments of Islamic Banking}

The basic paradigm of Islamic banking cannot be altered and the sharia unequivocally prohibits paying and receiving interest - riba - on financial transactions: money is just a medium of exchange, not an asset that can earn a return on itself (El-Gamal, 2006). Accordingly, shariacompliant banks cannot pay or charge a fixed, predetermined rate of return on deposits and loans. In other words, since the time value of money is recognized only as a part of a real economic transaction under the Islamic financial paradigm, banks function as investment companies and depositors behave like shareholders who earn dividends for their investment (Khan, 1991). In turn, lenders and borrowers in an Islamic financial transaction are essentially engaged in venture financing and hence share the associated risks and profits.

Under the sharia-compliant banking model, the assets and liabilities of banks should be integrated in a manner such that both depositors and borrowers share profits and losses with financial intermediaries. In a PLS-based transaction, the bank provides funding to an investment project and receives a pre-determined share of profits. If the project is successful and the firm earns a profit, the firm will retain a portion of profits and pass on the remainder to the bank according to a predetermined ratio. On the other hand, if the project turns out to be unsuccessful, the bank will lose all or part of its investment. Likewise, the bank will share its earnings with its depositors according to a pre-agreed share of profits. In this model, the return on Islamic investment accounts becomes a function of profitability in the real economy; and the bank's profit margin is determined by the difference between its predetermined ratio of earnings from the mobilization of investable funds and the amount it pays to depositors.

Theoretically, Islamic banking works through participatory instruments like mudaraba and musharaka as the main platform for deposit collection and the allocation of investable funds. These equity participation methods are similar to modern venture capital financing. Mudaraba is a form of financing under which the bank provides funding for investment and the borrower provides knowledge and entrepreneurial skills. The bank is not involved in actual management. Profits, if any, are shared according to a pre-determined ratio whereas losses are borne by the bank. Musharaka, on the other hand, is a type of equity participation under which the bank and the borrower contribute jointly to finance an investment project and the distribution of profits is based on a pre-agreed ratio, while the loss is assumed by partners according to their respective capital contributions. Although equity participation with risk sharing is the central tenet, Islamic banks also use debt-like instruments including murabaha, istisna and ijara that are based on deferred obligation contracts with mark-up financing for payment smoothing similar to conventional credit facilities (Aggarwal and Yousef, 2000). Murabaha and its variants are basically a form of repurchase contract in which the bank purchases a tangible asset at the request of the borrower and sells it to the borrower at a cost-plus markup price with installment repayments, similar to a conventional loan. Similarly, istisna is a predelivery financing instrument used mainly to fund long-term projects, and ijara is a contract through which the borrower leases an asset for a specified price and term.

\section{Some Factual Observations}

Flexibility of returns is an important reason why some analysts advocate the sharia-compliant financial system as a theoretically superior alternative to conventional banking. In an equity-based system with no pre-determined, fixed interest rate, changes in asset valuations would be absorbed by a corresponding change in the value of deposit accounts, and the structure of an Islamic bank's balance sheet would remain robust at all times, in contrast to the balance sheet stress that can arise with 
conventional banking. In practice, however, sharia-compliant banks tend to have different structures on the asset- and liability-sides of their balance sheets. While risk-sharing PLS instruments are the primary method for deposit collection, most Islamic banks rely on debt-like instruments that are based on deferred obligation contracts with mark-up financing and a guaranteed profit margin. ${ }^{5}$ Moreover, Islamic banks tend to link the mark-up to a conventional interest rate, typically the London Interbank Offered Rate (LIBOR) or a domestic equivalent. As a result, in the case of such debt-like instruments, the pricing of Islamic financing is not a function of real economic activity but is based on a predetermined interest rate plus a credit risk premium, similar to conventional loans.

The average rate of return on PLS investment accounts moves in tandem with conventional deposit rates. Between January 1997 and August 2010 the average and median returns on Islamic investment accounts of one-year maturity were 4.2 percent and 3.6 percent, respectively in Malaysia, and 44 percent and 35.7 percent in Turkey, compared to the average and median conventional oneyear deposit rates of 4.4 percent and 3.8 percent in Malaysia and 44.6 percent and 29.2 percent in Turkey. A possible explanation of these findings is that Islamic banks smooth profit disbursements over time by recourse to their profit equalization reserves in order to sustain a stable rate of return to depositors and remain competitive with conventional banks (Hassan and Lewis, 2009). Nevertheless, while relying on PLS accounts in funding activities, Islamic banks' earnings come from debt-like credit arrangements that are linked to prevailing conventional interest rates. Accordingly, the payments by Islamic banks to PLS account holders converge towards and move in tandem with conventional banks' deposit rates. ${ }^{6}$

The determination of PLS returns and conventional deposit rates overlaps because of the implicit link to interest-based credit pricing. In a simplified model, the average lending rate is determined by the average deposit rate conventional banks pay to raise funds, assuming no other form of funding, plus a term premium incorporating the length of the loan and a credit risk premium reflecting liquidity constraints and the probability of default. Depending on the profitability of the loan portfolio, new credit demand, and money market rates, conventional banks determine deposit rates and, correspondingly, the benchmark loan rate. On the other hand, the price of equity capital provided by Islamic banks should be based on a pre-determined ratio of profits earned on investment projects, moving with the rate of economic growth and the behavior of asset prices. Since the PLS model accounts for a small portion of asset creation in Islamic banks, which mainly use debt-like instruments to allocate their investable funds, the average return on assets becomes dependent on conventional bank charges for similar loans. Islamic banks may also be constrained by competitive pressures, especially in countries where conventional banks account for the majority of the banking system, therefore limiting the extent to which the rate of return on PLS accounts deviates from that on conventional bank deposits.

\section{Data}

The analysis is based on monthly average data on conventional and Islamic deposit rates in Malaysia and Turkey from January 1997 to August $2010 .^{7}$ Well-established dual banking systems in Malaysia and Turkey provide the basis for this study. ${ }^{8}$ The share of Islamic banks in banking system assets in Malaysia increased from 7 percent in 2000 to over 20 percent in 2010. In Turkey, the share of

\footnotetext{
${ }^{5}$ It has been noted in the literature that the PLS model is susceptible to asymmetric information and agency problems, which increase the cost of screening, monitoring, and contract enforcement relative to other forms of financing (El-Gamal, 2005). Equity participation-based products are also not easily adaptable to consumer and government finance. Furthermore, PLS instruments suffer from the lack of secondary market trading.

${ }^{6}$ It should be noted that Islamic banks in Malaysia (i) are subsidiaries of conventional banks; (ii) rely less on PLS accounts and more on reverse Murabaha-type deposits with a fixed return; (iii) make greater use of smoothing mechanisms; and, (iv) benefit from a well-developed Islamic money market.

${ }^{7}$ The interest rate data for Malaysia were obtained from the Central Bank website. For Turkey, the conventional bank deposit rates were obtained from the Central Bank of Turkey and the Islamic bank returns were obtained from the Participation Banks Association of Turkey.

${ }^{8}$ As of end-2010, there were 17 banks licensed to engage in Islamic banking in Malaysia, including Islamic banking operations as part of a conventional commercial bank, while there were four "participation banks" in Turkey, where conventional banks are not permitted to have an Islamic banking window.
} 
Islamic banks (known as "participation banks") grew from 2.1 percent in 2000 to 4.3 percent of total banking system assets at end-2010. The balance sheet structure of Islamic banks is similar in both countries, with PLS accounts representing about 90 percent of non-equity liabilities, while debt-like instruments are the principal conduit for asset creation. In the econometric analysis the following time series are used: MLCB1Y and MLIB1Y, which represent weighted-average interest rates on a oneyear term deposit in a conventional bank and in an Islamic bank in Malaysia; and TRCB1Y and TRIB1Y, which represent weighted-average conventional and Islamic deposit rates, respectively, in Turkey. ${ }^{\prime}$

\section{Econometric Methodology}

The nature and extent of association between the returns on conventional and Islamic deposits are examined using four econometric tools. The empirical methodology of this paper includes a test for cointegration between returns on conventional and Islamic deposits; a test for causality between the two types of deposits; the VECM approach to analyze the impulse response function to identify inter-temporal linkages between variables; and, an investigation of the correlation of volatility between the two types of retail deposits.

The cointegration approach provides a direct test of whether the rate of PLS returns is positively related to conventional interest rates. Both conventional and Islamic bank deposit returns indicate a clear trend over the sample period, but standard correlation statistics and regression tests may not be appropriate, since regressing non-stationary time series can lead to biased coefficients and seemingly significant results while there is actually no underlying association between variables. Accordingly, the augmented Dickey-Fuller (ADF) test is performed to investigate whether the series are non-stationary and integrated of order one. ${ }^{10}$ After testing whether conventional and Islamic bank deposit returns are integrated at same order, cointegration analyses is conducted to assess the longterm relationship. There are alternative techniques to examine the existence of a non-spurious relationship between two variables, and this study relies on the maximum likelihood cointegration methodology developed by Johansen (1988) and Johansen and Juselius (1990), as it allows for testing cointegration in a system of equations in one step and also avoids a priori assumptions of endogenity or exogeniety of variables. Cointegrated variables exhibit a common stochastic drift and share a certain type of behavior in terms of their long-term fluctuations. The Johansen cointegration procedure evaluates whether a long-run linear combination of variables is stationary, with a null hypothesis that the number of cointegrating vectors is less than or equal to the cointegrating rank. ${ }^{11}$

The direction of causality between conventional deposit rates and the rate of return on Islamic investment accounts is explored. The existence of cointegration indicates the possibility of a causal link between conventional and Islamic bank deposit returns, but does not identify the direction of causality between the two variables. To determine the direction of causality, the pairwise causality test developed by Granger (1969) is used to examine a series of null hypotheses for the Malaysian and the Turkish cases: PLS returns do not Granger cause conventional bank deposit rates; conventional bank deposit rates Granger cause PLS returns; changes in PLS returns do not Granger cause a corresponding change in conventional bank deposit rates; and, changes in conventional bank deposit rates Granger cause a change in PLS returns. Since the pairwise Granger causality test may produce ambiguous results when the true nature of relationship involves a common third process and the results obtained with a Granger test provide little or no insight into the sign and magnitude of the causality effect the data is analyzed further in a vector autoregressive model (VAR) model.

Additional variables such as consumer price inflation are introduced to examine further the causal relations and dynamic interactions between conventional and Islamic bank deposit returns with

\footnotetext{
${ }^{9}$ Although the analysis is based on one-year term deposit rates, an analysis of one- or three-month deposit rates does not change the main conclusions.

${ }^{10}$ The objective of the ADF procedure is to test the null hypothesis that a series contains a unit root. If the null hypothesis can be rejected then the variable is stationary. If not, the series should be transformed through differencing until stationarity is established. The most common occurrence in macro-financial variables is that the first-differenced values are stationary, in which case the variable is integrated of order one.

${ }^{11}$ Hamilton (1994) provides a comprehensive presentation of the cointegration framework and alternative tests.
} 
the VECM approach - a restricted form of a VAR - designed to handle cointegrated non-stationary series. The advantage of using the VECM is that it identifies inter-temporal linkages between variables and allows the short-run dynamics of each variable in the system to be anchored to the long-run equilibrium relationship. If two or more non-stationary series are cointegrated, the VECM restricts the long-run behavior of the endogenous variables to converge to their cointegrating equilibrium while still allowing for short-run adjustment dynamics. ${ }^{12}$ In addition, the impulse response function and variance decomposition are analyzed to provide further information regarding the sign and timing of adjustment. Moreover, to study the evolution of time-varying volatility and correlations, the twelvemonth rolling standard deviation of conventional and Islamic deposit returns is examined. ${ }^{13}$

\section{Interpreting the Empirical Results}

The ADF unit root test is conducted for each variable with an intercept term and, alternatively, both intercept and trend, with a lag specification based on the Schwarz criterion. ${ }^{14}$ The results, presented in Table 1, show that conventional and Islamic bank deposit returns are non-stationary in level, irrespective of whether a constant term or both intercept and trend terms are included. The null hypothesis of non-stationarity can be rejected for the first differences of all the variables at the one percent significance level, indicating that both conventional and Islamic bank deposit returns in Malaysia and Turkey are integrated of order one and may have a long-run cointegration relationship. The stationarity of additional time series are investigated: MLINFLATION and TRINFLATION, which represent consumer price inflation in Malaysia and Turkey, respectively. According to the ADF test results, inflation in Malaysia is stationary in level at the five percent significance level, but stationary in first difference at the one percent level. On the other hand, Turkish inflation is nonstationary in level and stationary in first differences at the one percent significance level, which might be due to structural breaks reflecting the burst of volatility during the 2001-02 crisis as well as rapid disinflation following the introduction of the inflation targeting regime.

Table 1. Unit Root Test Results



Notes:

${ }^{1}$ The test statistics are compared to the critical values from MacKinnon (1996).

${ }^{2}$ Lag specification is based on Schwarz criterion.

$3 *$ and ${ }^{* *}$ denote that the null hypothesis can be rejected at 5 percent significance level and 1 percent significance level, respectively.

Source: Authors' calculations.

The Johansen cointegration procedure is used to analyze the relationship between conventional and Islamic bank deposit returns in Malaysia and Turkey. The trace statistic is greater than the critical value, therefore the null hypothesis of no cointegration between conventional and Islamic bank deposit returns over the long run can be rejected-a result also confirmed by the

\footnotetext{
${ }^{12}$ In a two variable system with one cointegrating equation, as is the case with conventional and Islamic bank deposit returns, the VECM can be expressed in the following equations: $\Delta I B_{t}=\theta_{1}\left(C B_{t-i}-\beta I B_{t-i}\right)+u_{1, t}$ and $\Delta C B_{t}=\theta_{2}\left(C B_{t-i}-\beta I B_{t-i}\right)+u_{2, t}$, where $u_{1, t}$ and $u_{2, t}$ are white noise disturbances and $\theta_{1}$ and $\theta_{2}$ represent the speed of adjustment.

13 Data limitations prevented the application of generalized autoregressive conditional heteroskedasticity (GARCH) models to estimate the conditional volatility of conventional and Islamic bank deposit returns.

${ }^{14}$ The intercept is included because all the variables have a non-zero mean, while the trend term allows for the possibility of a deterministic time trend.
} 
maximum eigenvalue statistics in both countries. The results, reported in Table 2, show that PLS returns are cointegrated with conventional deposit rates at the five percent significance level in Malaysia and in Turkey. In other words, conventional bank deposit rates and Islamic bank PLS returns share a common trend and long-run equilibrium. The inclusion of consumer price indices indicates that inflation is also cointegrated with PLS returns (and conventional bank deposit rates) in Malaysia, but not in Turkey.

Table 2. Cointegration Test Results

\begin{tabular}{lccccc}
\hline Dependent & \multicolumn{2}{c}{$\begin{array}{l}\text { Independent } \\
\text { Variable }\end{array}$} & & \multicolumn{3}{c}{ Trace Statistics } \\
\cline { 3 - 5 } MLIB1Y & MLCB1Y & & None & At most 1 & At most 2 \\
\hline MLIB1Y & MLCB1Y & MLINFLATION & $37.62604^{*}$ & 6.25450 \\
TRIB1Y & TRCB1Y & & $17.239667^{*}$ & $16.15370^{*}$ & 3.807803 \\
TRIB1Y & TRCB1Y & TRINFLATION & $30.50073^{*}$ & 9.056323 & \\
\hline
\end{tabular}

Notes:

${ }^{1}$ The test statistics are compared to the critical values from MacKinnon-Haug-Michelis (1999).

${ }^{2}$ Lag specification is based on Schwarz criterion.

3 The null hypothesis is that there is no cointegration.

4 * Denotes that the null hypothesis can be rejected at 5 percent signficance level.

Source: Authors' calculations.

The pairwise Granger causality test results, reported in Table 3, indicate that the null hypothesis that changes in PLS returns do not Granger cause changes in conventional deposit rates both in Malaysia and Turkey cannot be rejected, but the null hypothesis that changes in conventional deposit rates do not Granger cause changes in PLS returns can be rejected. Similarly, as set out in Table 3, the empirical results show that there is Granger causality between conventional deposit rates and the rate of return on Islamic investment accounts over the sample period, with the direction of causality running from conventional bank deposit rates to the rate of return on Islamic investment accounts in Malaysia and Turkey. Nevertheless, the Granger causality test may yield ambiguous results when the true nature of relationship involves a common third process and provides little insight as to the sign and magnitude of the causality effect. For that reason the causal relations and dynamic interactions between conventional and Islamic bank deposit returns are examined within a VECM framework to identify the inter-temporal linkages between variables.

Table 3. Granger Causality Test Results

\begin{tabular}{lcc}
\hline & F-Statistic & Prob. \\
\hline MLCB1Y does not Granger Cause MLIB1Y & $23.178^{*}$ & $6.00 \mathrm{E}-15$ \\
MLIB1Y does not Granger Cause MLCB1Y & 0.16045 & 0.958 \\
MLCB1Y(-1) does not Granger Cause MLIB1Y(-1) & $23.1705^{\star}$ & $6.00 \mathrm{E}-15$ \\
MLIB1Y(-1) does not Granger Cause MLCB1Y(-1) & 0.15818 & 0.9590 \\
& & \\
TRCB1Y does not Granger Cause TRIB1Y & $5.2378^{*}$ & 0.0006 \\
TRIB1Y does not Granger Cause TRCB1Y & 0.98477 & 0.4177 \\
TRCB1Y(-1) does not Granger Cause TRIB1Y(-1) & $5.22024^{*}$ & 0.0006 \\
TRIB1Y(-1) does not Granger Cause TRCB1Y(-1) & 0.97972 & 0.4205 \\
\hline
\end{tabular}

Notes:

${ }^{1}$ The results are based on 4 lags, but robust across all lag specifications.

2 * Denotes that the null hypothesis can be rejected at 5 percent significance level.

Source: Authors' calculations.

The VECM approach provides further evidence of the relationship between conventional interest rates and retail PLS returns. Additional variables are introduced including consumer price inflation to examine the dynamic interactions between conventional and Islamic bank deposit returns 
within a VAR framework. ${ }^{15}$ Since these variables are cointegrated, the appropriate approach is a VECM which allows exploration of the short- and long-run dynamics among the variables. The VECM results, presented in Table 4 for Malaysia and Table 5 for Turkey, show that while the error correction term is negative and statistically significant in the PLS return equation both in Malaysia and Turkey, the corresponding error correction term has no statistical significance in the conventional deposit rate equation. In other words, retail PLS returns are strongly influenced by conventional interest rates and, to a lesser extent, by consumer price inflation.

Table 4. Malaysia: Vector Error Correction Estimates

\begin{tabular}{lccc}
\hline Cointegrating equation: & Cointegrating equation 1 & & \\
\hline MLIB1Y(-1) & 1.000000 & & \\
MLCB1Y(-1) & -0.798453 & & \\
& $(0.05170)$ & & \\
MLINFLATION(-1) & {$[-15.4441]$} & & \\
& -0.256299 & & \\
C & $(0.06759)$ & & \\
\hline Error correction: & {$[-3.79199]$} & $\mathrm{D}(\mathrm{MLCB} 1 \mathrm{Y})$ & $\mathrm{D}(\mathrm{MLINFLATION})$ \\
\hline Cointegrating equation 1 & -0.53565 & 0.061454 & 0.498925 \\
& $\mathrm{D}(\mathrm{MLIB} 1 \mathrm{Y})$ & $(0.08590)$ & $(0.17347)$ \\
& -0.125465 & & {$[2.87621]$} \\
\hline
\end{tabular}

Notes:

${ }^{1}$ Standard errors are in paranthesis and t-statistics are in brackets.

${ }^{2}$ Lag order is selected according to the Akaike information criterion.

Source: Authors' calculations.

Table 5. Turkey: Vector Error Correction Estimates

\begin{tabular}{|c|c|c|c|}
\hline Cointegrating equation: & Cointegrating equation 1 & & \\
\hline TRIB1Y(-1) & 1.000000 & & \\
\hline \multirow[t]{3}{*}{ TRCB1Y(-1) } & -1.689402 & & \\
\hline & $(0.28564)$ & & \\
\hline & {$[-5.91446]$} & & \\
\hline \multirow[t]{3}{*}{ TRINFLATION(-1) } & 0.618198 & & \\
\hline & (0.26889) & & \\
\hline & [2.29905] & & \\
\hline C & 9.641141 & & \\
\hline Error correction: & D(TRIB1Y) & D(TRCB1Y) & D(TRINFLATION) \\
\hline \multirow[t]{3}{*}{ Cointegrating equation 1} & -0.025602 & 0.024574 & -0.028053 \\
\hline & $(0.00658)$ & $(0.01898)$ & $(0.00983)$ \\
\hline & {$[-3.89356]$} & [1.29507] & {$[-2.85267]$} \\
\hline
\end{tabular}

Notes:

${ }^{1}$ Standard errors are in paranthesis and t-statistics are in brackets.

${ }^{2}$ Lag order is selected according to the Akaike information criterion.

Source: Authors' calculations.

With the error correction methodology, causality tests confirm the findings based on the pairwise Granger causality test. In the case of Malaysia, changes in conventional bank deposit rate Granger cause changes in PLS returns and there is no direct causal relationship between inflation and PLS returns (Table 6). In the case of Turkey, similar results are obtained, indicating that the direction of causality runs from changes in conventional bank deposit rates to the rate of return on Islamic investment accounts, but there is no causal linkage between inflation and retail PLS returns (Table 6).

\footnotetext{
15 The expected rate of consumer price inflation would be a more appropriate metric, especially for investment returns, but limitations in data availability prevented the use of expected inflation rates.
} 
Table 6. VEC Granger Causality Tests

\begin{tabular}{lccc}
\hline & Chi-sq & df & Prob. \\
\hline Dependent variable: D(MLIB1Y) & & & \\
D(MLCB1Y) & 56.55271 & 11 & $0^{0.0000^{*}}$ \\
D(MLINFLATION) & 26.41582 & 11 & $\begin{array}{l}0.0056^{*} \\
0.0000^{*}\end{array}$ \\
All & 103.8471 & 22 & \\
Dependent variable: D(MLCB1Y) & & & \\
D(MLIB1Y) & 9.991623 & 11 & 0.5311 \\
D(MLINFLATION) & 13.09418 & 11 & 0.2872 \\
All & 21.50084 & 22 & 0.4900 \\
Dependent variable: D(TRIB1Y) & & & \\
D(TRCB1Y) & 6.401125 & 2 & $0.0407^{*}$ \\
D(TRINFLATION) & 1.000566 & 2 & 0.6064 \\
All & 7.693005 & 4 & 0.1035 \\
Dependent variable: D(TRCB1Y) & & & \\
D(TRIB1Y) & 0.130541 & 2 & 0.9368 \\
D(TRINFLATION) & 0.497758 & 2 & 0.7797 \\
All & 0.692763 & 4 & 0.9522 \\
\hline
\end{tabular}

Notes:

${ }^{1}$ Lag order is selected according to the Akaike information criterion.

2 * Denotes that the null hypothesis can be rejected at 5 percent significance level.

Source: Authors' calculations.

The impulse response function provides the sign and time path of the dependent variables in the VECM to shocks from the exogenous factors. Accordingly, an analysis of the impulse response function and the variance decomposition provides more definitive evidence than the Granger causality test. The time-varying response of retail PLS returns to changes in conventional interest rates and consumer price inflation are set out in Figure 2 for Malaysia and in Figure 3 for Turkey. While the impact of changes in conventional interest rates on retail PLS returns is marked, statistically significant, and long-lived, the effect of a change in PLS returns on conventional interest rates is minimal and statistically insignificant. In the case of Malaysia, a one standard deviation change in conventional interest rates leads to a change of 0.34 in PLS returns over a twelve-month period, whereas a corresponding change in PLS returns has an impact of 0.13 on conventional bank deposit rates during the same period and fades away over the following twelve months. In Turkey, the impulse response of retail PLS returns to a one standard deviation change in conventional interest rates is even more pronounced: 1.83 in the first twelve months and increasing to 2.22 in the following period without any sign of fading.

Figure 2. Malaysia: Response to Cholesky One S.D. Innovations
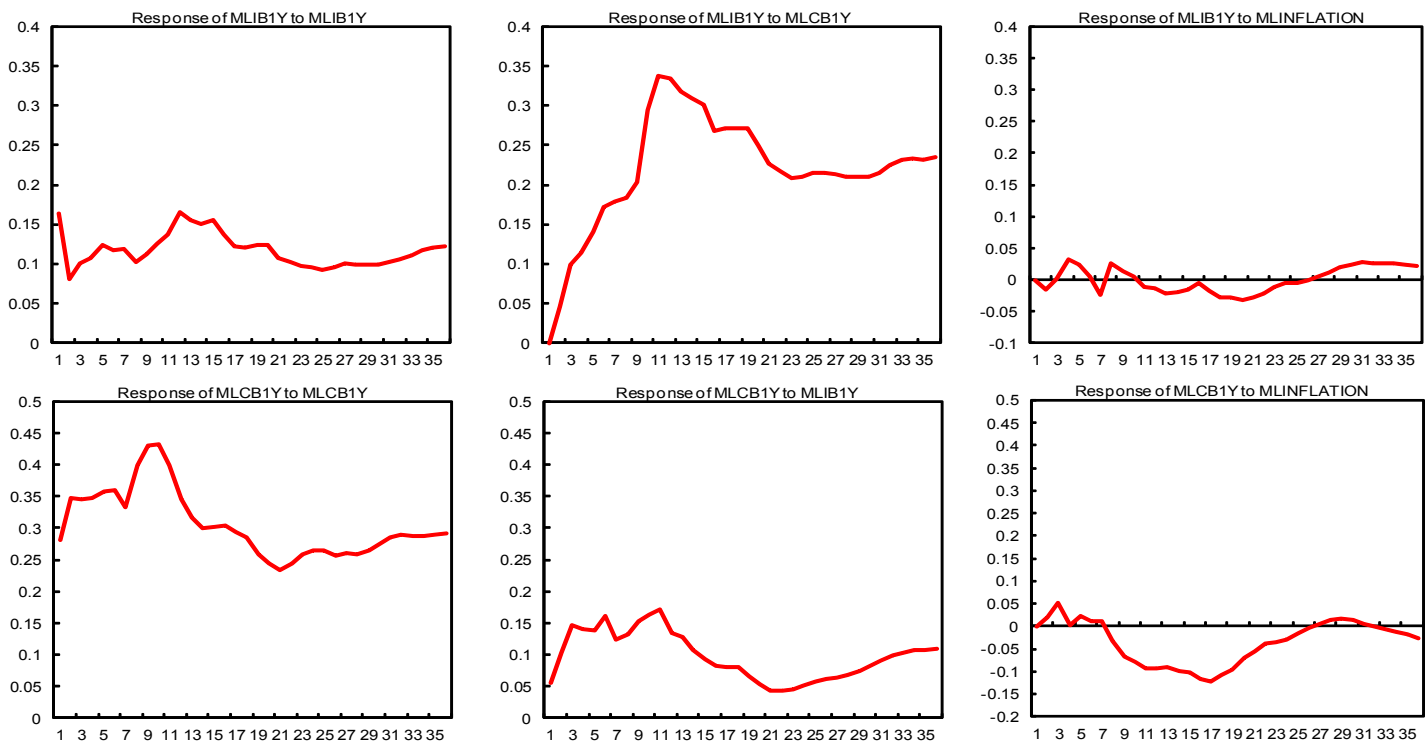

Source: Authors' calculations. 
Figure 3. Turkey: Response to Cholesky One S.D. Innovations
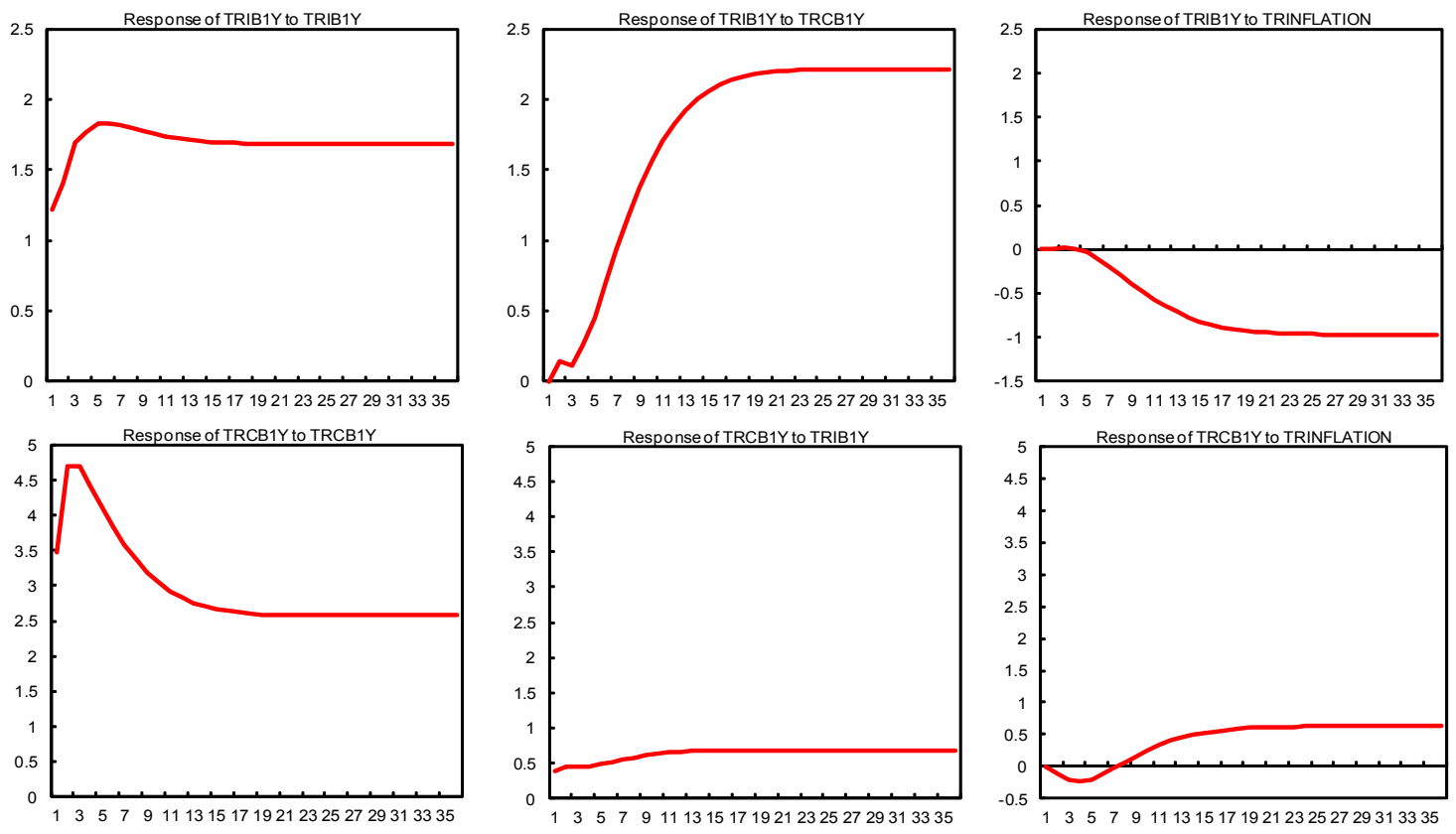

Source: Authors' calculations.

While the impulse response function traces the impact of a change in one variable to the other variables in the system, variance decomposition divides the variation in a dependent variable into the component shocks to the system. In other words, the variance decomposition of the VECM provides information about the relative significance of each random shock in affecting the variables in the system. As illustrated in Figure 4 for Malaysia and Figure 5 for Turkey, the results show that much of the variation in PLS returns is explained by conventional interest rates, whereas there is little or no relationship the other way around. In Malaysia, the variation in conventional bank deposit rates accounts for 73 percent of the variation in PLS returns in the first twelve months and 78 percent in the following twelve months, whereas the variation in PLS returns may explain just 12 percent of the variation in conventional interest rates in the first twelve months and less than 10 percent in the following twelve months. In the case of Turkey, the variation in PLS returns due to conventional interest rates is 27 percent in the first twelve months and increases to 50 percent in the next twelve months, while PLS returns account for only 2 percent of the variation in conventional bank deposit rates over the first twelve months and 3.5 percent in the following twelve months. These results are consistent with findings confirming the direction of causality running from conventional interest rates to PLS returns.

The time-varying volatility patterns of PLS returns and conventional interest rates are investigated by examining rolling standard deviations. The twelve-month rolling standard deviation on conventional and Islamic bank deposit returns in Malaysia and Turkey is computed-MLCBSDEV, MLIBSDEV, TRCBSDEV, and TRIBSDEV, respectively - then the correlation is examined. As set out in Table 7 the correlation for Malaysia is 0.66 and is statistically significant. Similarly, as set out in Table 8, the correlation for Turkey is 0.62 and is statistically significant. During a macroeconomic crisis (1997-98 in Malaysia and 2000-01 in Turkey) the volatility of conventional bank deposit rates and PLS returns diverged. In Malaysia, the Asian crisis led to an increase of 300 basis points in conventional bank deposit rates from 7.3 percent at the beginning of 1997 to a peak of 10.3 percent in mid-1998, whereas the increase in retail Islamic bank deposit returns was limited to 230 basis points. In Turkey, the severe shock of the 2001 crisis led to a surge of 3800 basis points in conventional deposits rates between November 2000 and March 2001, while PLS returns declined by 1200 basis points over the same period. 
Figure 4. Malaysia: Variance Decomposition
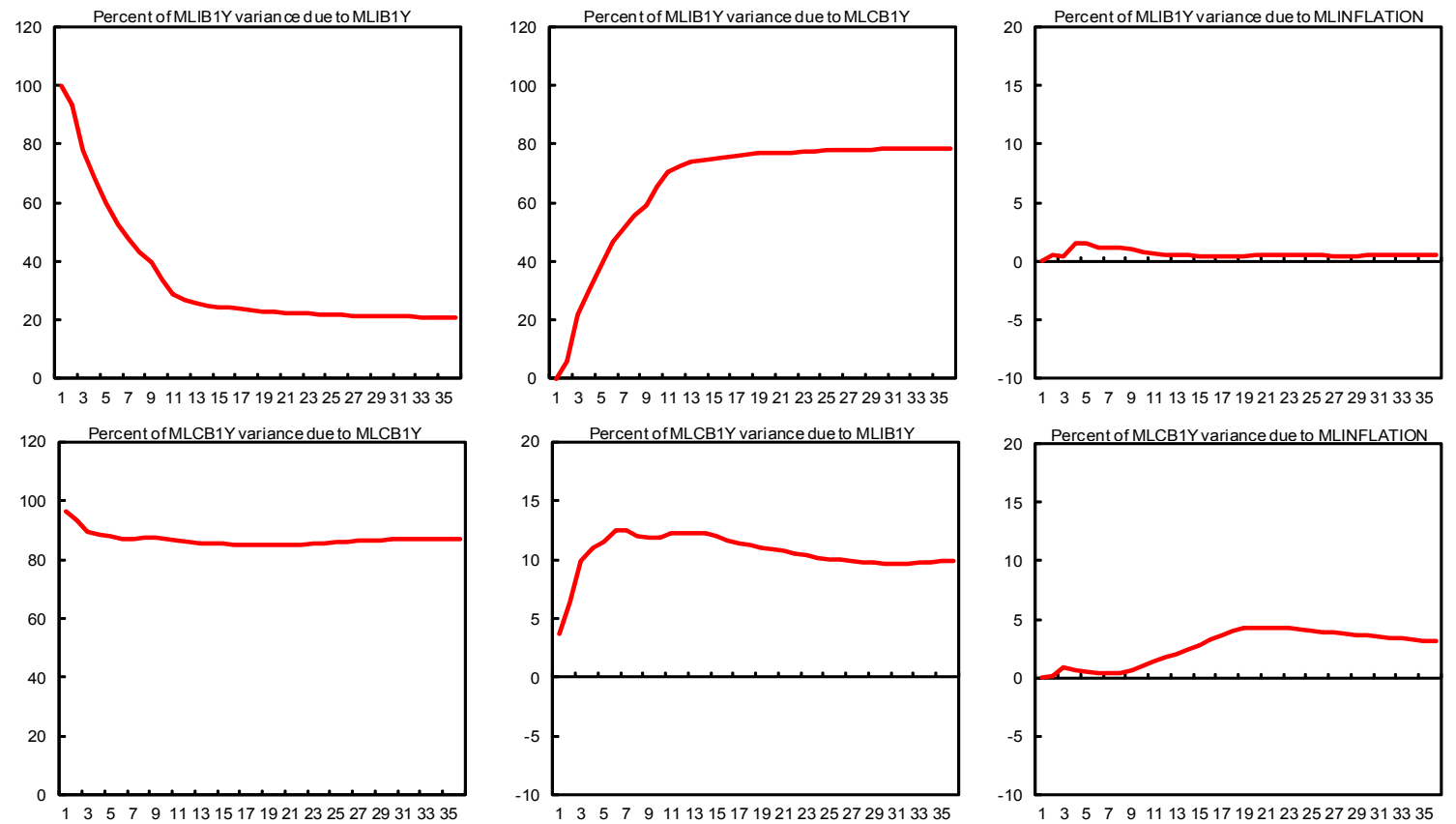

Source: Authors' calculations.

Figure 5. Turkey: Variance Decomposition
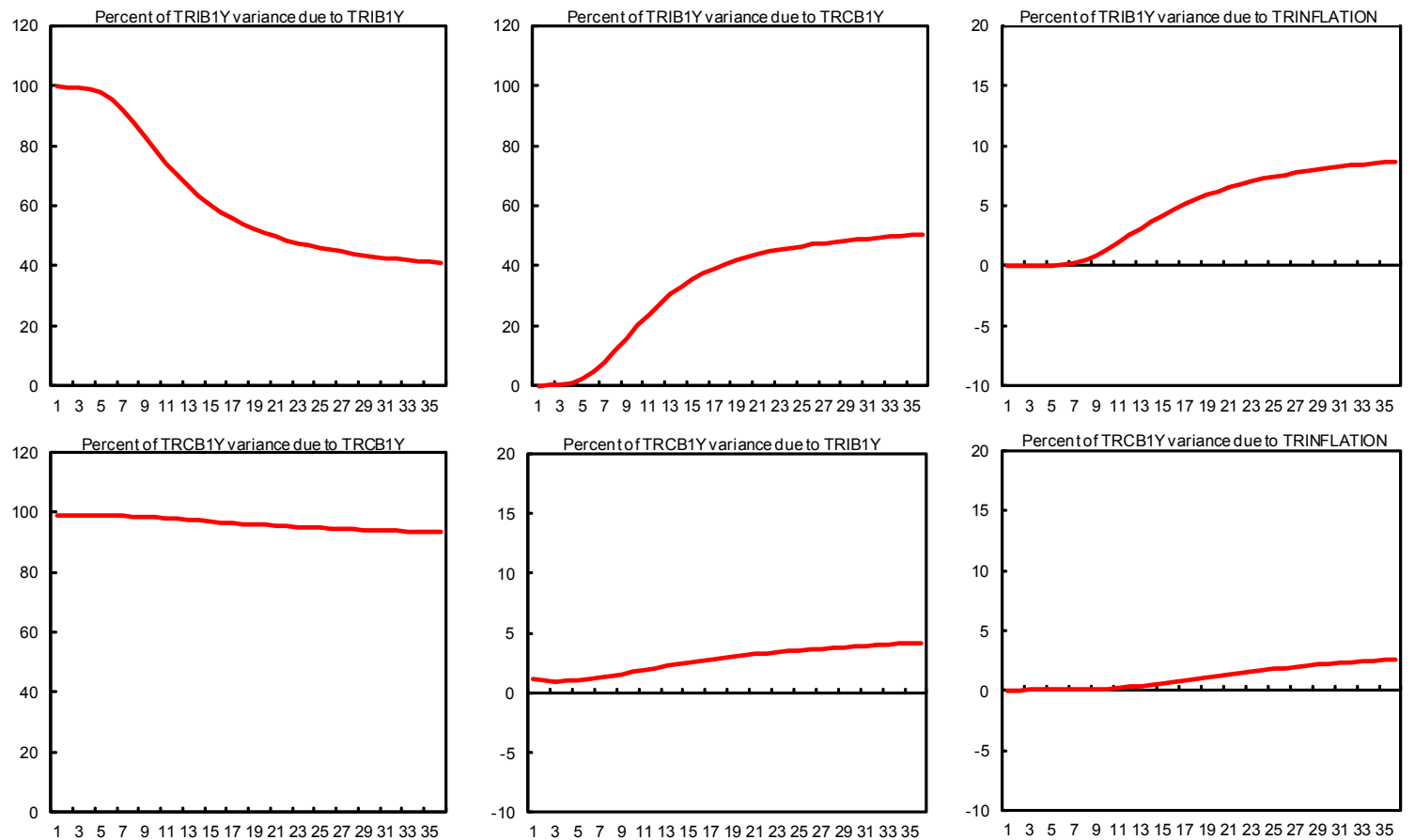

Source: Authors' calculations. 
Table 7. Malaysia: Correlation of 12-Month Rolling Standard Deviation of Deposit Rates

\begin{tabular}{lrrr} 
& & MLCBSDEV & MLIBSDEV \\
\cline { 2 - 4 } Correlation & & 1.0 & \\
t-Statistic & & - & \\
Probability & & & \\
& & & \\
Correlation & MLIBSDEV & 0.66253 & 1.0 \\
t-Statistic & & 10.86891 & -- \\
Probability & & 0.0 & - \\
\hline
\end{tabular}

Source: Authors' calculations.

Table 8. Turkey: Correlation of 12-Month Rolling Standard Deviation of Deposit Rates

\begin{tabular}{lrrr}
\hline & & TRCBSDEV & TRIBSDEV \\
\cline { 2 - 4 } Correlation & TRCBSDEV & 1.0 & \\
t-Statistic & & - & \\
Probability & & - & \\
& & & \\
Correlation & TRIBSDEV & 0.623294 & 1.0 \\
t-Statistic & & 9.794486 & - \\
Probability & & 0.0 & - \\
\hline
\end{tabular}

Source: Authors' calculations.

During the global financial crisis, the divergence between conventional and retail Islamic deposit returns was less pronounced than during earlier crises. In the case of Malaysia, conventional one-year term deposit rates declined by 20 basis points in the second half of 2008 and 50 basis points in 2009, while Islamic bank deposit returns recorded a drop of 60 basis points in the second half of 2008 and 60 basis points in 2009. In Turkey, although the immediate response to the crisis diverged in the second half of 2008 with a 300 basis points increase in conventional bank deposit rates compared to a 50 basis point increase in PLS returns, the behavior of conventional and Islamic deposit rates converged, with a drop of 470 basis points in 2009. While an analysis of the balance sheet performance of conventional and Islamic banks during macro-financial crises is beyond the scope of this paper, conventional banks are more dependent on wholesale funding than their Islamic counterparts and, consequently, seem more vulnerable to macro-financial frictions that result in volatility bursts and higher funding costs during severe shocks. In addition, interest rate averages mask the funding pressures caused by a few banks under severe stress and consequently may result in temporary divergences.

\section{Conclusion}

The empirical analysis shows that PLS returns and conventional bank deposit rates exhibit cointegration over the long run: conventional bank interest rates and the rates of return on retail Islamic investment accounts move together. The results also indicate that the time-varying volatility of PLS returns and conventional bank deposit rates is correlated and is statistically significant. Moreover, the pairwise and multivariate causality tests show that changes in PLS returns are determined by changes in conventional bank deposit rates.

The rate of return on retail PLS accounts is implicitly linked to conventional interest rates through debt-like instruments on the asset side. While retail sharia-compliant banks collect deposits through the Islamic model, we find strong evidence that they follow their conventional counterparts in creating assets through non-PLS, debt-like instruments with a pre-determined, fixed rate of return. As a result, there is an implicit link to interest rates on the asset side of the balance sheets and the rate of return on Islamic investment accounts follows conventional bank deposit rates. We have shown that 
the rate of return on retail Islamic investment accounts closely follows the behavior of interest rates provided by conventional banks and we offer several possible explanations as to why the asset side of retail Islamic banks is similar to that of conventional banks:

- Islamic financing encounters moral hazard problems associated with ex-post information asymmetry in PLS instruments. For example, the borrower has an incentive to under-declare profits and/or undertake high-risk projects, as the borrower gains on the upside but faces limited losses on the downside. Consequently, the cost of monitoring is much higher in the PLS model.

- The adoption of PLS financing is constrained by the scope to exercise management and control rights. In mudaraba, for example, the bank provides the capital, but management and control of the project is in the hands of the entrepreneur. Weaknesses in the possibility to exercise management and control accentuate the principal-agent problems associated with the PLS model of financing.

- $\quad$ PLS-based instruments require lengthy due diligence and therefore are not always appropriate or cost effective for short-term financing needs.

- $\quad$ The lack of secondary markets for PLS-based financial products complicates liquidity and credit risk management at Islamic banks.

- $\quad$ The adoption of the PLS paradigm is constrained by competition as well as by best practices in the conventional banking sector. Individuals can choose to bank with a sharia-compliant bank or a conventional bank, which, at the margin, can drive Islamic banks to effectively peg PLS returns to conventional bank deposit rates.

- Islamic banks tend to use non-participatory, debt-like instruments in creating assets, while funding their operations mainly through the participatory PLS model, and are able to remain competitive with conventional banks through utilization of profit equalization reserves.

The empirical results of this paper have important policy implications for the central banks and the financial regulators in terms of price stability and financial stability. Although the behavior of conventional and retail Islamic bank deposit rates occasionally diverges, there is a long-run relationship that may necessitate comparability of treatment from a regulatory point of view and in terms of assessing the impact on monetary policy transmission. The global financial crisis has necessitated the modernization of regulatory frameworks, including a comprehensive reassessment of macro-prudential policies. The contractual complexity of PLS-based transactions gives rise to operational risks stemming from information asymmetries. Likewise, the limitations on secondary markets for PLS instruments - and interbank markets in general - has inhibited the development of participatory financing and encouraged Islamic banks to pursue short-term asset creation with debtlike credit products.

Several areas deserve further research, including the balance sheet vulnerabilities of conventional and Islamic banks to macro-financial shocks. In light of our econometric findings that the rate of return on retail sharia-compliant investment accounts is cointegrated with conventional bank deposit rates and that conventional interest rates Granger cause PLS returns, it would be useful to extend our research to a larger sample of countries, especially in the Middle East where Islamic banking is rapidly becoming a substantial part of the financial system. Another interesting question, particularly from the impact of sharia-compliant financial intermediation on economic growth, is whether the behavior of credit pricing by Islamic banks differs from conventional lending practices across a broader sample. It is also timely to examine more closely the vulnerabilities of conventional and Islamic bank balance sheets to macro-financial shocks.

\section{Acknowledgements}

The authors would like to thank Joseph Crowley, Sergei Dodzin, Christian Harm, Maher Hasan, Katerina Kalcheva, Hakan Kara, May Khamis, Subir Lall, Adnan Mazarei, Tigran Poghosyan, Faezeh Raei, David Robinson, Tahsin Saadi Sedik, Abdelhak Senhadji, Gabriel Sensenbrenner, Ahmet Tiktik, and Rachel van Elkan for their insightful comments and suggestions. Responsibility for any errors and omissions lies with the authors. 


\section{References}

Aggarwal, R., Yousef, T. (2000), Islamic Banks and Investment Financing, Journal of Money, Credit, and Banking, 32, 93-120.

Beck, T., Demirguc-Kunt, A., Merrouche, O. (2010), Islamic vs. Conventional Banking: Business Model, Efficiency and Stability, World Bank Policy Research Working Paper, No. 5446.

Bollerslev, T. (1986), Generalized Autoregressive Conditional Heteroskedasticity, Journal of Econometrics, 31, 307-327.

Chong, B., Liu, M-H. (2009), Islamic Banking: Interest-Free or Interest-Based?, Pacific-Basin Finance Journal, 17, 124-144.

Dridi, J., Hasan, M. (2010), Have Islamic Banks Been Impacted Differently than Conventional Banks During the Recent Global Crisis? IMF Working Paper, No. WP/10/201 (Washington: International Monetary Fund).

Ebrahim, M., Safadi, A. (1995), Behavioral Norms in the Islamic Doctrine of Economics: A Comment, Journal of Economic Behavior of Organization, 27(1), 151-157.

El-Gamal, M. (2005), Mutuality as an Antidote to Rent-Seeking Sharia-Arbitrage in Islamic Finance, http://www.ruf.rice.edu/ elgamal/.

El-Gamal, M. (2006), Islamic Finance: Law, Economics and Practice, Cambridge, United Kingdom: Cambridge University Press.

Engle, R. (1982), Autoregressive Conditional Heteroskedasticity with Estimates of the Variance of UK Inflation, Econometrica, 50, 987-1008.

Engle, R., Kroner, K. (1995), Multivariate Simultaneous GARCH, Economic Theory, 11, 122-150.

Granger, C. (1969), Investigating Causal Relation by Econometric Models and Cross-Spectral Methods, Econometrica, 37, 424-438.

Hamilton, J. (19949, Time Series Analysis, Princeton, NJ: Princeton University Press.

Hassan, M., Lewis, M. (2009), Handbook of Islamic Banking, Northampton, MA: Edward lgar Publishing.

Imam, P., Kpodar, K. (2010), Islamic Banking: How Has It Diffused? IMF Working Paper, No. WP/10/195 (Washington: International Monetary Fund).

Johansen, S. (1988), Statistical Analysis of Cointegrating Vectors, Journal of Economic Dynamics and Control, 12, 231-254.

Johansen, S., Juselius, K. (1990), Maximum Likelihood Estimation and Inference on Cointegrationwith Applications to the Demand for Money, Oxford Bulletin of Economics and Statistics, 52, 169-210.

Khan, M. (1986), Islamic Interest-Free Banking: A Theoretical Analysis, Staff Papers, International Monetary Fund, 33, 1-27.

Khan, M. (1991), Time Value of Money and Discounting in Islamic Perspective, Review of Islamic Economics, 1(2), 35-45.

Mills, P., Presley, J. (1999), Islamic Finance: Theory and Practice, London, United Kingdom: Macmillan. 